The main result of the transplantation experiments has been the demonstration that the material basis of resistance and susceptibility to carbon dioxide does not leave the ovary during the intensive histological changes during the pupal period. It cannot be transferred even under the most favourable conditions. Consequently it is perhaps better described as a plasmagene $e^{t 5}$ than as a virus, for the time
being. We should like to thank Prof. B. Ephroussi and Dr. A. C. Faberg6 for advice on the technique and Miss J. Bathgate for technical assist. ance during the work.

$$
\text { H. KALMUS. }
$$

Department of Biometry, Eugenics and Genetics, University College.

Gower Street, London, W.C.1.

Sept. 27.

' L'Héritier and Teissier, C.R. Acad. Sci., 205, 1099 (1937); 206, 1193, $1683(1938)$

${ }^{2}$ L'Héritier and Teissier, Proc. 7th Internat. Congress of Genetics, Edin. 1939 (1941).

3 Ephroussi, B., and Beadle, G. W., Amer. Nat., 70, 218 (1936).

5 Parter

\section{Blood Group A Substances in Commercial Hog Stomach} Powder

IN a search for a convenient source of substances with blood group A specificity, dried hog stomach powder (Boots 'Pepsac') proved suitable. The usual sources, namely, dry gastric mucus and saliva from human secretors, were not readily available.

In a comparison of various methods of isolation, potent preparations were obtained, in emall quantities, by ethanol-acetate precipitation, and by precipitation with anhydrous sodium sulphate ${ }^{1}$ from watery extracts of the powder. Both methods gave viscous substances which

frothed reation.

Both preparations contained a protein fraction, giving a pink biuret colour and a positive ninhydrin reaction. The ethanol-acetate substance gave positive xanthoproteic and Millon reactions, while the sodium sulphate substance was but weakly positive with the former and negative with the latter test.

The Molisch reaction was strongly positive with both substances, while both gave a colour characteristic of hexoses and methylpentoses with $\beta$-naphthol reagent ${ }^{2}$. Neither preparation had any reducing properties before hydrolysis. The naphtho-resorcinol test for glycuronates was negative (weak green fluorescent ether extract) and the orcin test (Bial) for pentoses was negative. The sodium sulphate preparation gave a very weak pink colour in Tollens test for pentoses, being, however, too faint for satisfactory spectroscopic investigation.

The sodium sulphate preparation was the more potent in inhibition of Group $A$ isoagglutination, being active at dilutions of $1 / 50,000$ of the dry substance. It was some 1.5 times as active as the ethanolacetate preparation, and flfty times as active as the original powder In addition, there was inhibition of 0 a

Until the deproteinized substances are available in larger a mounts, potencies and physico-chemical properties cannot be assessed in absolute terms. The comparison of these and other methods of isolation is in progress, which may also reveal possible effects of manufacturing processes on the potency and characteristics of the specific substance present.

Department of Pathology,

M. E. FOLAN.

University College,

Cork.

${ }^{1}$ Morgan, W. T. J., and King, H. K., Biochem. J., 37, 640 (1943).

'Thomas, P., Bull. Soc. Chim. Biol., 7, 102 (1925)

s Witebsky, E., and Klendshoj, N. C., J. Exper. Med., 73, 655 (1941)

Addition Compounds between Sucrose and the Sodium Halides

A COMPOUND between sucrose and sodium chloride has been described by a number of investigators, the most complete account being that of $\mathrm{Gill}^{1}$, who ascribed to it the formula $\mathrm{C}_{12} \mathrm{H}_{22} \mathrm{O}_{11} \cdot \mathrm{NaCl}_{2} \mathrm{H}_{2} \mathrm{O}$. Gil also obtained addition compounds with sodium bromide and sodium and $2 \mathrm{C}_{12} \mathrm{H}_{22} \mathrm{O}_{11} .3 \mathrm{NaI} .3 \mathrm{H}_{2} \mathrm{O}$. In the course of an investigation of sucrose by the methods of $X$-ray crystallography, it became of interes to investigate these compounds more fully.

An aqueous solution of two molecular proportions of sucrose to three of sodium bromide, left to evaporate for a period of months, deposited crystals of the composition shown below:

$\begin{array}{ccc}\text { Sucrose } & \mathrm{NaBr} & \begin{array}{c}\text { Water } \\ \text { (by difference) }\end{array} \\ 71 \cdot 3 \text { per cent } & 21 \cdot 4 \text { per cent } & 7 \cdot 3 \text { per cent } \\ 71 \cdot 1 \text { By measurement } \\ \text { By calculation from }\end{array}$

The crystals are orthorhombic, and have the form of prisms with sides parallel to the $c$-axis. X-ray examination shows a unit cell of dimensions : $a=21 \cdot 9_{2}, b=9 \cdot 7_{2}, c=8 \cdot 4_{3}$ A. The space group is $P 2_{1} 2_{1} 2_{1}$, the unit cell containing four molecules of sucrose, four of crystals is $1 \cdot 78_{3} \mathrm{gm}$./c.c.; calculated from the dimensions of the unit cell it is $1.77 \mathrm{gm} . / \mathrm{c} . \mathrm{c}$.
The compound between sucrose and sodium chloride has been prepared by slow evaporation of an aqueous solution containing on molecular proportion of sucrose to two of sodium chloride. Crystals of varying composition, from almost pure sugar to pure salt, were deposited, a mong which a few small crysta is of $\mathrm{C}_{12} \mathrm{H}_{22} \mathrm{O}_{11} \cdot \mathrm{NaCl}_{2} \mathrm{H}_{2} \mathrm{O}$ were identifled by taking $X$-ray rotation photographs. This compound is isomorphous with that described above. The replacement of bromine by chlorine causes the unit cell to contract by about 2 per cent so that $a=21 \cdot 7_{5}, b=9 \cdot 6_{2}, c=8 \cdot 4_{0}$ A. The measured density 1.574).

A compound between sucrose and sodium iodide has been prepared and has been found to be identical with that described by Gill in density, chemical composition and crystallographic form. Unlike the two compounds already described, this substance is very easy to prepare: it crystallizes rapidly from a solution in water of sucrose and sodium iodide in almost any proportions. The approximate dimensions of the monoclinic unit cell are $a=29 \cdot 4, b=8 \cdot 2, c=$ $8 \cdot 50 \mathrm{~A} ., \beta=94 \cdot 05^{\circ}$. It thus contains two of the complex molecules

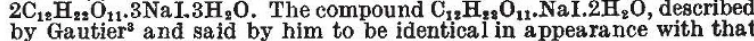
described by Gill, has not been obtained by us.

A complete $\mathrm{X}$-ray investigation of the two compounds flrst described is at present being carried out. The fact that they are isomorphous is at present being carried out. The fact that they are isomorphous to be fixed, and two-dimensional Fourier synthesis, leading to maps to be fixed, and two-dimensional Fourier synthesis, leading to maps of the electron density projected on the planes $(001)$, $(010)$, (100) can then be carried out. It is anticipated that further

I am indebted to Dr. C. A. Beevers for facilities to undertake this work.

Dewar Crystallographic Laboratory,

W. COCHRAN.

University of Edinburgh. Oct. 5 .

${ }^{1}$ J. Chem. Soc., 24, 269 (1871).

Bull. Soc. Chem., (2), 15, 1 (1871)

${ }^{3}$ C.R. Acad. Sci., Paris, 138, 638 (1904).

\section{Chemistry and Biochemistry of the Scent Glands of the} Beaver (Castor fiber)

I HAVE just found a short reference in the Bulletin Analytique to a preliminary note of $\mathbf{P}$. G. Stevens ${ }^{1}$ on "American musk. II. A preliminary note on the scent glands of the beaver" , describing the isolahave been published since on that subject.

I have been working on the constituents of castoreum, the dried scent glands of the Canadian beaver (Castor fiber), since 1940, and have published flve papers on that subject in the Travaux des Membres Soc. Chim de Chimie biologique. (The Marseilles edition of the Bull. censored by the Gas published during the occupation without being Zentralblattor apparently by Chemical Abstracts.) The flrst paper ${ }^{2}$ describes the isolation of seven aromatic acids : benzoic hydrocinnamic, salicylic, $m$-oxy-benzoic, $p$-oxy-benzoic, anisic and gentisic acids. The second paper ${ }^{8}$ reports the isolation and chemical constitution of two yellow pigments, parents of ellagic acid. The first, $\mathrm{C}_{13} \mathrm{H}_{8} \mathrm{O}_{4}$, m.p. above $360^{\circ}$, diacetate F. $210^{\circ}$, dimethyl-ether m.p. 151-153 is a 8 -monolactone of a trihydroxy-diphenic acid (probably 4-4. m.p. above $360^{\circ}$, diacetate F.326, dimethyl-ether m.p. above $350^{\circ}$, is a $\delta, \delta$-dilactone of a tetrahydroxy-diphenic acid (hydroxyls probis a $\delta, \delta$-dilactone of a tetrahydroxy-diphenic acid (hydroxyls prob-
ably in $\left.4,4^{\prime}, 6,6^{\prime}\right)$. Both pigments yield fluorene on distillation with zinc dust. The third paper ${ }^{4}$ describes the isolation of seven phenols : ga iacol, creosol, pyrocatechol, hydroquinol, monomethylether of hydroga iacol, creosol, pyrocatechol, hydroquinol, monomethylether of hydro-
quinol, betuligenol ( $(-)-p \cdot$ oxyphenyl-butanol-3) (see Sosa $)^{7}$ and

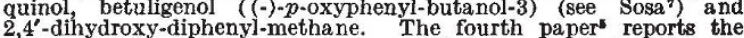
isolation of the following aldehydes and ketones: salicylic aldehyde, isolation of the following aldehydes and ketones: salicylic aldehyde, acetophenone, $p$-oxy-acetophenone, $p$-methoxy-acetophenone, ${ }_{2}{ }^{2}$ neutral a romatic methoxy-cetone $\mathrm{C}_{10} \mathrm{H}_{12} \mathrm{O}_{2}$ and two cetones, $\mathrm{C}_{18} \mathrm{H}_{23} \mathrm{O}_{8}$ or $\mathrm{C}_{18} \mathrm{H}_{24} \mathrm{O}_{2}$ (2,4-dinitrophenylhydrazones m.p. $120-122^{\circ}$ and $\left.167-169^{\circ}\right)$. benzyl alcohol, borneol, a saturated monocyclic bisecondary glycol benzyl alcohol, borneol, a saturated monocyclic bisecondary giycol $\mathrm{C}_{12} \mathrm{H}_{24} \mathrm{O}_{2}$ containing one or two $\mathrm{CH}_{3} \mathrm{CHOH}$-groups, cholesterol containing 3.4 per cent of $\beta$-cholestanol, a phenolic ether $\mathrm{C}_{18} \mathrm{H}_{18} \mathrm{O}_{2}, \mathrm{~m} . \mathrm{p}$. $84^{\circ}$, containing the a nisyl group and, finally a tertiary amine, castor-
a mine, $\mathrm{C}_{15} \mathrm{H}_{28} \mathrm{O} \mathrm{N}$, m.p. $65-66^{\circ},[a] p=-31^{\circ}$, which contains no amine, $\mathrm{C}_{15} \mathrm{H}_{28} \mathrm{O}_{2} \mathrm{~N}$, m.p. $65-66^{\circ},[a] D=-31^{\circ}$, which conte
methoxyl or methylimide group, nor any mobile hydrogen.

I now wish to report the isolation of some more substances which will be described more fully in a future communication. These are $p$-propyl-phenol, chavicol, ethyl-gaiacol, methyl-pyrocatechol, ethylpyrocatechol, three unidentifled phenols (m.p. $135^{\circ}, \mathrm{C}_{21} \mathrm{H}_{8} \mathrm{O}_{2}$, m.p. 360 ), cinnamic acid, a hydroxyphenyl-propionic acid m.p. 103-105 5-methoxy-salicylic acid, a phenolic acid m.p. $102^{\circ}$, methyl salicylate, a phenolic ester m.p. $170^{\circ}$, cholesterol oleate, a waxy substance, presumably a mixture of esters of 'cerylic alcohol', and a hydrosoluble nitrogen-free substance melting at $173^{\circ}$. We hope to identify some of these substances as soon as micro-analyses will again be feasible Benzyl alcohol exists in the scent glands in the free form and as neutra. and phenolic esters. Gentisic acid and other phenolic acids are presen as esters with neutral alcohols and, principally, with other phenols.

The presence of all these substances in an animal gland is ver surprising. We believe it to be due to the unusual excretion metabolism of the beaver, which deposits the aromatic substances of its food (mostly bark and buds of trees) in its scent glands, instead of excreting them in the urine. A great number of the above-named substances have indeed been found in the urine of vertebrates. Some substances are deposited unchanged, some after saponiflcation of the glucoside linkage (piceoside $\rightarrow p$-oxy-acetophenone; betuloside $\rightarrow$ 